OPEN ACCESS

Edited by:

Go Iwahana,

University of Alaska Fairbanks, United States

Reviewed by: Nicolas Jelinski,

University of Minnesota Twin Cities, United States Chien-Lu Ping, University of Alaska Fairbanks, United States

*Correspondence: Roman Desyatkin rvdes@ibpc.ysn.ru rvdes@mail.ru

Specialty section: This article was submitted to Cryospheric Sciences, a section of the journal Frontiers in Earth Science

Received: 22 March 2021

Accepted: 23 August 2021 Published: 24 September 2021

Citation:

Desyatkin R, Filippov N, Desyatkin A, Konyushkov $D$ and Goryachkin S (2021) Degradation of Arable Soils in Central Yakutia: Negative Consequences of Global Warming for Yedoma Landscapes.

Front. Earth Sci. 9:683730. doi: 10.3389/feart.2021.683730

\section{Degradation of Arable Soils in Central Yakutia: Negative Consequences of Global Warming for Yedoma Landscapes}

\author{
Roman Desyatkin ${ }^{1 *}$, Nikolai Filippov ${ }^{1}$, Alexey Desyatkin ${ }^{1}$, Dmitry Konyushkov ${ }^{2}$ and \\ Sergey Goryachkin ${ }^{3}$
}

${ }^{1}$ Laboratory of Ecosystem Research of Cold Regions, Institute of Biological Problems of the Cryolithozone, Siberian Branch of the Russian Academy of Sciences, Yakutsk, Russia, ${ }^{2}$ Department of Genesis, Geography, Classification and Digital Cartography of Soils, Dokuchaev Soil Science Institute, Russian Academy of Sciences, Moscow, Russia, ${ }^{3}$ Department of Soil Geography and Evolution, Institute of Geography, Russian Academy of Sciences, Moscow, Russia

Global warming, which is especially intensive (up to $0.08^{\circ} \mathrm{C} y r^{-1}$ ) in permafrost area of Central Yakutia, has dramatic consequences for scarce arable land resources in this region. In Yedoma landscapes, intense permafrost thawing on arable fields unprotected by forest vegetation transforms the surface microtopography with the formation of residual thermokarst mounds (byllars) of 6-10 $\mathrm{m}$ in diameter surrounded by a polygonal network of hollows of $0.3-1.5 \mathrm{~m}$ in depth above melting ice wedges. This process also takes place on former croplands abandoned in the recent decades because of socioeconomic reasons. It is accompanied by a significant transformation of the previously highly likely homogeneous soil cover composed of Cambic Turbic Cryosols (Sodic) into differentiated complexes of permafrost-affected Stagnic Cambisols or Calcic Solonetzes (Turbic) on the mounds and Calcic Stagnic Solonetzes (Turbic) in the microlows. Surface soil horizons on the mounds have a strongly to very strongly alkaline reaction $(\mathrm{pH} 8.5-9.5)$ and low $(<2 \%)$ organic carbon content; a wavy line of effervescence is found at a depth of $15-30 \mathrm{~cm}$. Soils in the microlows have a close to neutral reaction in the upper horizons $(\mathrm{pH} \mathrm{6.2-7.5);} \mathrm{higher}$ organic carbon content (2-3\%); more pronounced textural differentiation of the profile with the formation of typical natric Btn and, in some cases, overlying eluvial E horizons; deeper (50-60 cm) line of effervescence; and clear stagnic features in the lower part of the profile. In the case of shallow embedding by ice wedge, the lowermost part of the soil in the microlow is characterized by the low bulk density $\left(1.04 \mathrm{~g} \mathrm{~cm}^{-3}\right)$ because of the appearance of hollows after thawing of the ice-rich transient layer and melting of the top of ice wedges. This may be indicative of the further soil subsidence in the future and the appearance of initial thermokarst lakes (dyuedya) within the Yedoma terrain with its transformation into the alas type of landscape. Rapid thermokarst-driven development of microtopography followed by differentiation of the soil cover with increasing soil alkalinity on the microhighs and soil textural differentiation and overmoistening of deep layers in the microlows prevents the return of abandoned arable land to agriculture in Yedoma landscapes.

Keywords: permafrost thawing, abandoned arable land, Cambic Turbic Cryosols, Calcic Stagnic Solonetzes, thermokarst formation, boreal forest zone 


\section{INTRODUCTION}

Global climate change poses a serious challenge for humankind (IPCC, 2014). It is a well-known factor of changes in world agriculture and food supply (Rosenzweig and Parry, 1994). In the recent decades, unprecedented climate changes have taken place in the Arctic and the adjacent area of continental permafrost (Schuur and Mack, 2018). The rise in temperature in the northern high-latitude regions has been 2.5 times faster than on the entire Earth (IPCC, 2014). This phenomenon has attracted the attention of specialists in agriculture sending them in search of new opportunities for sustainable farming in these traditionally poorly cultivated areas both in the entire Circumpolar North (Poeplau et al., 2019) and in its particular regions (Stevenson et al., 2014; Lader et al., 2019). Some tendencies of the development of agriculture in cold regions seem to be very optimistic; thus, in 2012-2017, the number of farms in Alaska increased by up to $30 \%$ (Crampton, 2019). However, it is also known that cropland areas of the North display different tendencies. Thus, in most of northern Russia regions, a pronounced decrease in cropland area took place in the recent past (Lyuri and Goryachkin, 2008). The reasons for this decrease may be different. In this study, we consider adverse effects of natural processes taking place due to climate warming in the permafrost environment of Central Yakutia.

By the early 1640s, vast territories of Siberia were colonized by the Russian state. In the second half of the 17th century, after the integration of lands in the middle Lena reaches, Russian arable farming began to be practiced in this harsh environment (Safronov, 1961). Early-ripening varieties of grain crops-spring wheat, rye, and oats-were sown. Despite very unstable harvests from year to year, the area of arable land was gradually expanded to meet the needs of population. By the time of the collapse of the Soviet state, cropland area reached more than 140 thousand hectares (Desyatkin, 2004). After the collapse of the Soviet Union, state-owned agricultural enterprises ceased to exist. Since then, cropland area in the middle Lena basin has been decreasing from year to year. At present, there are no more than 40 thousand hectares of regularly cultivated cropland. Under conditions of global climate change, abandoned arable land is subjected to a strong transformation of the soil cover (Desyatkin, 2018).

In the presence of ice-rich permafrost with ice wedges (Yedoma, Ice Complex deposits), an increase in the depth of seasonal soil thawing leads to the melting of underground ice (Jorgenson et al., 2015; Veremeeva et al., 2021). In this case, not only the release of additional moisture previously stored in the permafrost (Jorgenson, 2013) but also the formation of deep thermokarst hollows above melting ice wedges take place (Jorgenson et al., 2015). These processes are well known for permafrost-affected terrain involved in agriculture in Alaska (Péwé, 1954). Degradation of the Yedoma ice complex proceeds until the ice reserves are completely depleted (Shur and Jorgenson, 2007). As a rule, thermal erosion of the Yedoma ice complex is associated with physical soil erosion and redeposition of soil material and proceeds at a relatively fast rate leading to the formation of young thermokarst landscapes and changing the water budget of permafrost territories (Desyatkin and Desyatkin, 2019).

The entire territory of the Republic of Sakha (Yakutia) lies in the permafrost zone. Especially, noticeable processes of transformation of the soil cover occur in the most developed agricultural regions of Central Yakutia-the Lena-Amga interfluve and, to a smaller extent, the Tabaga area on the left bank of the Lena River (Boike et al., 2016). As a result of the collapse of large agricultural enterprises in the early 1990s, thousands of hectares of arable land developed from under taiga vegetation on the Yedoma ice complex have been abandoned in the recent decades in these regions. The thermokarst process on arable land leads to the transformation of the soil cover over large areas removed from the agricultural use.

In this study, we analyzed the change in morphological features and some properties of soils affected by agricultural land use and climate change in the Yedoma landscape of Central Yakutia and considered them in the context of climate-induced soil changes in other cold regions. However, we did not make a direct comparison of soils under intact forests and under cropland and did not evaluate the rate of these changes but instead focused on soil features occurring after decades of soil use in arable farming.

\section{MATERIALS AND METHODS}

\section{Study Area}

The research area is located in Central Yakutia, northeast Russia. The first study site-Churapcha-is located to the east of the Lena River, in the central part of the Lena-Amga interfluve near the town of Churapcha, on the medium-level ancient erosional-accumulative Abalakh terrace. The second site-Tabaga-is found to the west of the Lena River on the medium-level Tabaga terrace of approximately the same elevation near the village of Tabaga (Figure 1).

These terraces are composed of the Quaternary loamy and loamy sandy lacustrine-alluvial sediments with ice wedges (Figure 2) underlain by alluvial sands. The entire area lies in the zone of continuous permafrost with a thickness over $400 \mathrm{~m}$ and with temperatures at the base of the layer of annual temperature fluctuations varying from -1 to $-5^{\circ} \mathrm{C}$ (Brown et al., 1997).

The climate of the Lena-Amga interfluve belongs to the Dwc type according to the Köppen-Geiger climate classification system (Beck et al., 2018) and is characterized by the following parameters (Churapcha/Yakutsk ${ }^{1}$ weather stations): mean annual air temperature $-10.3 /-7.5^{\circ} \mathrm{C}$, mean air temperature of the warmest month (July) $18.7 / 20^{\circ} \mathrm{C}$, and mean air temperature of the coldest month (January) $-42.5 /-36.3^{\circ} \mathrm{C}$. Thus, the annual amplitude of mean monthly temperatures reaches $61.2 / 56.3^{\circ} \mathrm{C}$. The mean annual precipitation is $296 / 280 \mathrm{~mm}$ with a monthly minimum $(5 / 6 \mathrm{~mm})$ in February

${ }^{1}$ Yakutsk meteorological station is the nearest one $(\sim 30 \mathrm{~km})$ for the Tabaga site. 


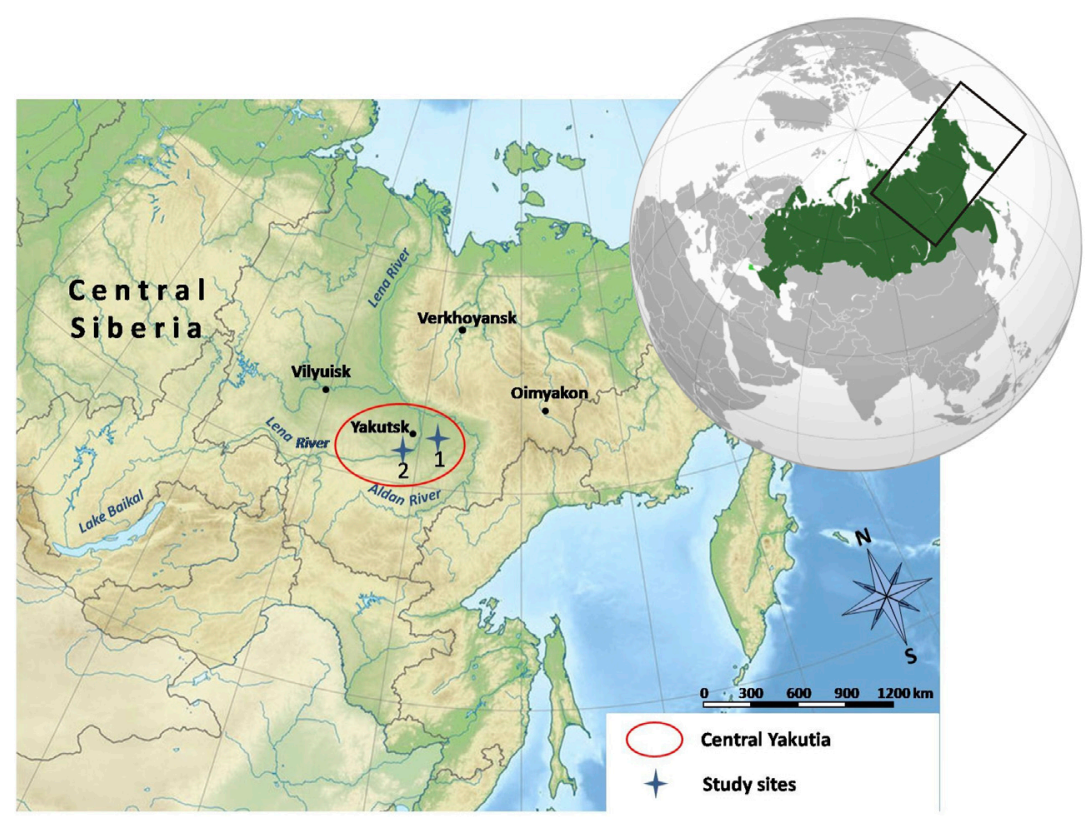

FIGURE 1 | Study area. Key sites: (1) Churapcha and (2) Tabaga.

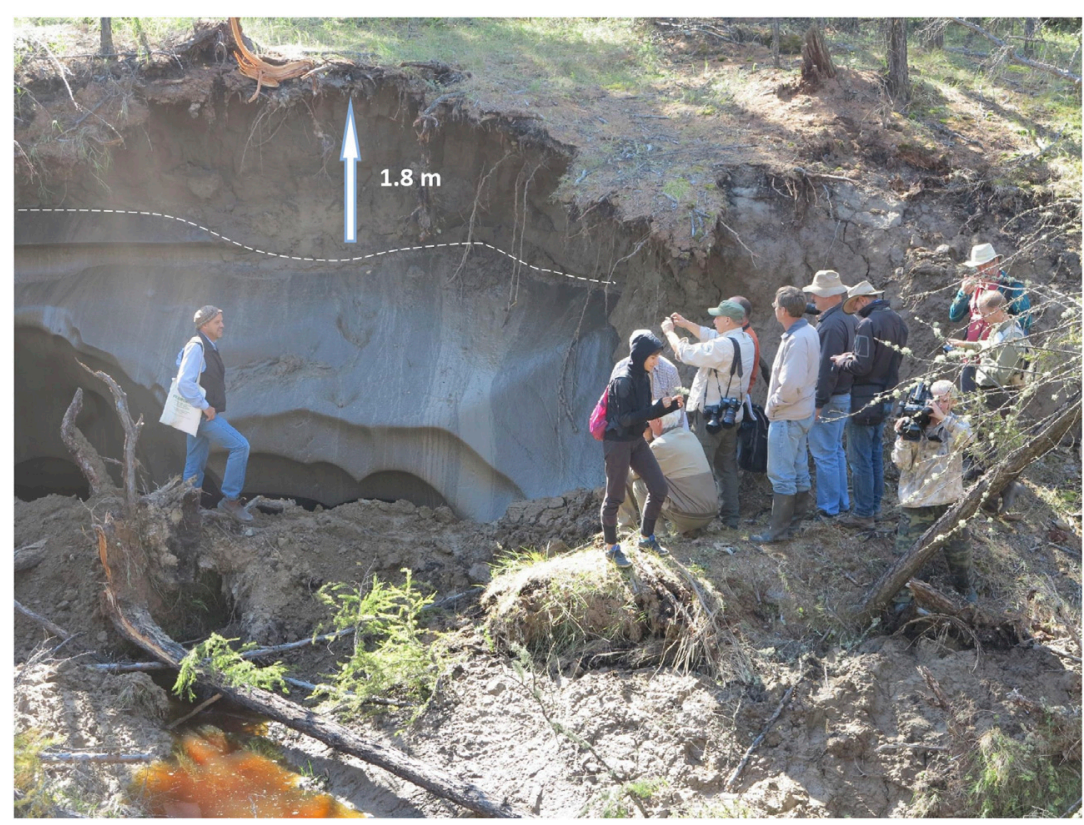

FIGURE 2 | The upper boundary of an ice wedge lies at a depth of about $2 \mathrm{~m}$.

and a maximum $(52 / 47 \mathrm{~mm})$ in July/August, respectively (https:// en.climate-data.org/asia/russian-federation/sakha-republic-875/).

In the past 30 years, climate warming in Central Yakutia has been clearly pronounced. The rate of the rise in the mean annual air temperature (up to $0.08^{\circ} \mathrm{C} / \mathrm{yr}$ ) in this area is one of the highest in Russia. In the 1960s-1970s, the warming was not so noticeable; it accelerated in the 1980s (Skachkov, 2000). The last decade of the 20th century with the mean annual air temperature of $-8.7^{\circ} \mathrm{C}$ was the warmest decade in the history of meteorological observations in Central Yakutia (Grigor'ev et al., 2010).

Since the appearance of permafrost (about 500-700 ka ago), soils have been developing within a thin active layer in the absence of drainage and active removal of the products of pedogenesis and weathering. Under these conditions, soil 


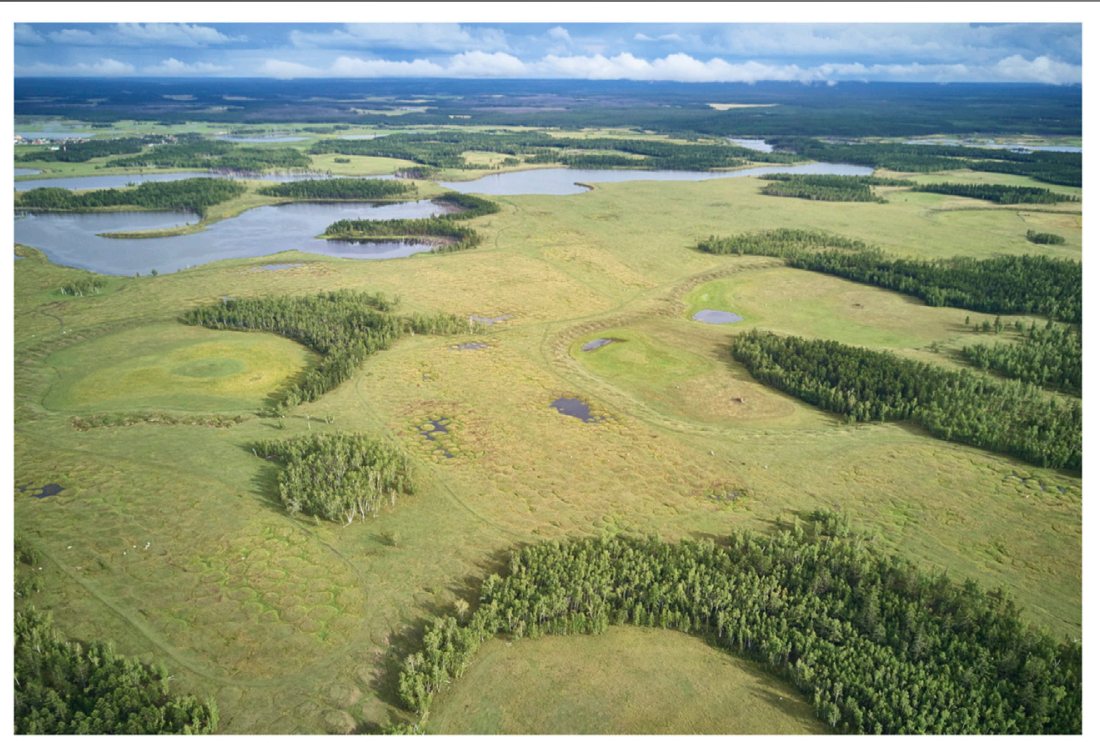

FIGURE 3 | The initial stage of thermokarst degradation of the soil cover of abandoned arable land in the area of Churapcha with typical Yedoma-alas landscape. Photo by K. Abrosimov.

solutions migrate only within the active layer, and the products of weathering and soil formation are gradually accumulated in it. Against the background of dry continental climate, this has resulted in the widespread soil salinization (Desyatkin, 1993).

Partial degradation of ground ice in this area in the Holocene led to the development of thermokarst Yedoma-alas landscape with lakes and meadows (Figure 3) (Veremeeva et al., 2021). Alases (thermokarst depressions) are characterized by herbaceous vegetation, under which a group of specific soils are developed (Desyatkin, 1991); some of them are saline (Desyatkin, 2008). Alases of different sizes (from dozens of meters to several kilometers) are scattered amidst the predominant boreal forest vegetation. On the map of terrestrial ecoregions of the world (Olson et al., 2001), this territory is shown as "Boreal forests/Taiga." Russian specialists name this territory as the Central Yakutia taiga-alas soil province (Elovskaya and Konorovskii, 1978). Forest vegetation in the region is represented by larch (Larix cajanderi L.) and birch (Betula pendula R.) forests with herbs in the ground cover (Timofeev et al., 1994).

Owing to the recent rise in air temperatures, the depth of seasonal soil thawing has increased throughout the studied area (Desyatkin et al., 2015). When the depth of seasonal soil thawing reaches the upper boundary of ice wedges of the Yedoma ice complex, their melting begins. This leads to the appearance of initial forms of alas development-byllars—-residual thermokarst mounds of up to $7-10 \mathrm{~m}$ in diameter and $0.5-1.6 \mathrm{~m}$ in height relative to the polygonal network of thermokarst hollows (microlows) forming above melting ice wedges (Figures 4, 5A) (Gavril'ev et al., 2005). In some places, ice melting leads to the formation of young and relatively small thermokarst lakes, dyuedya (Figure 5B). These processes were described in more detail earlier (Jones et al., 2009; Desyatkin et al., 2013). The appearance of the mound-hollow microrelief on the flat surface of abandoned arable land leads to land degradation and difficulty of its use for arable farming; it also causes transformation of the formerly more or less homogeneous soil cover of agricultural fields developed in the 1960s after clearing of forest vegetation.

Both study sites, as well as the entire territory of Central Yakutia, belong to the zone of high-risk farming under severe climatic conditions: a short growing season (65-100 days in dependence of the natural weather cycles), typical late spring and early summer (until June 15) and early autumn (after August 10-15) frosts, and wide interannual fluctuations of precipitation (from 75 to $250 \mathrm{~mm}$ during the warm season). In addition, farming is threatened by the periodic mass reproduction of locusts (up to $1,200-1,500$ insects $/ \mathrm{m}^{2}$ ). For these reasons, the yield of cereal crops in different years varies from $0.3-0.5$ to $1.5-2.8 \mathrm{t} / \mathrm{ha}$. The gross harvest of meadow roughage during the 11 -year solar cycle ranges from $0.2-0.3$ to $1.5-1.8 \mathrm{t} / \mathrm{ha}$. Under these conditions, the traditional branch of agriculture-cattle breeding and horse breeding-lacks solid fodder base and experiences wide fluctuations in the number of cattle and horses (Neustroev et al., 2017).

Field studies of the influence of initial thermokarst landforms on the morphogenetic properties of soils were performed in July 2012 on the arable field abandoned in the early 1990s, $1.5 \mathrm{~km}$ southeast of the town of Churapcha (site 1), and in August 2012, near Tabaga (site 2), where the cropland was abandoned in the early 1980. At the Churapcha site, soil pits were examined on the top (pit C-01-12) and slope (pit C-02-12) of a thermokarst mound (byllar) and in the bottom of a thermokarst hollow (microlow) between neighboring byllars (pit C-03-12); the hollow system had a polygonal pattern (Figure 4). On the tops of some byllars, the network of frost cracks could be observed. 


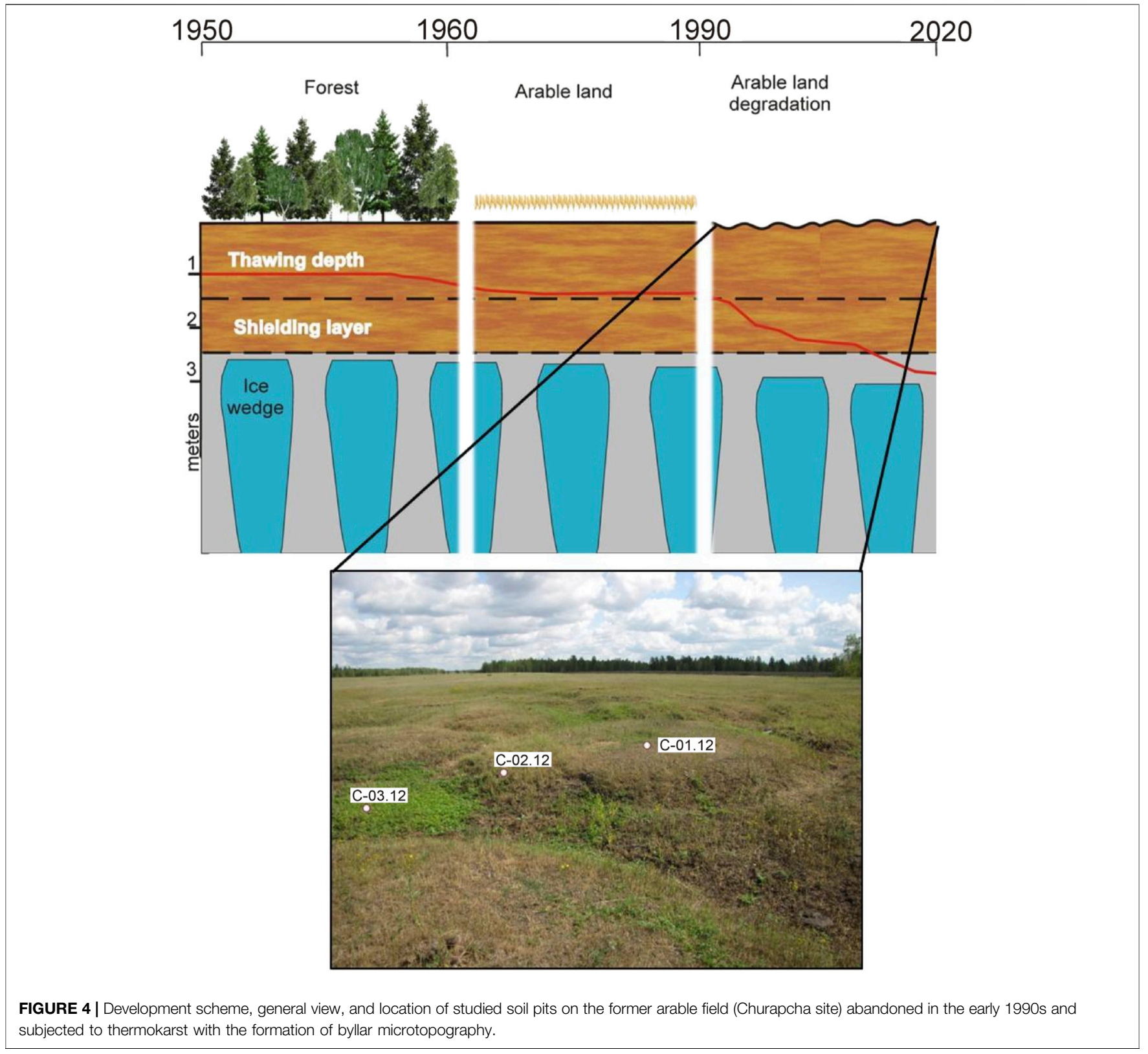

At the Tabaga site, a trench crossing the top of byllar (pit T2.1), the slope of neighboring byllar (pit T-2.2), and the microlow between byllars (pit T-2.3) were examined. In this case, the byllar microtopography was less pronounced: the diameter of thermokarst mounds was about $3-5 \mathrm{~m}$, and the amplitude of heights between their tops and microlows was about $0.5 \mathrm{~m}$ (Figure 5A). However, on an adjacent former arable field, the development of thermokarst processes was much more intense and led to the formation of thermokarst badland and initial small deeply (4-6 m) incised thermokarst lakes (dyuedya) (Figure 5B).

\section{Methods}

In the field, morphological descriptions of the soil profiles and measurements of thawing depths were conducted. Designation of soil horizons and soil names followed the Guidelines for Soil Description (FAO, 2006) and the WRB system (IUSS WG WRB, 2015). Physical soil samples were taken from every horizon and air-dried. Bulk density, $\mathrm{pH}$, particle-size distribution, and organic carbon content were determined in the samples taken with a cutting ring of $100 \mathrm{~cm}^{3}$ in volume from each soil horizon in triplicate.

The $\mathrm{pH}$ of soil water suspensions (1:2.5) was measured with an F-8 pH meter (Horiba, Japan) after shaking the suspensions for $2 \mathrm{~h}$, or once mixing by hand and standing for $30 \mathrm{~min}$. The bulk density was determined by the gravimetric method with the soil drying in a thermostat at $105^{\circ} \mathrm{C}$.

The organic carbon content was determined by wet combustion using Tyurin's method. This procedure is similar 


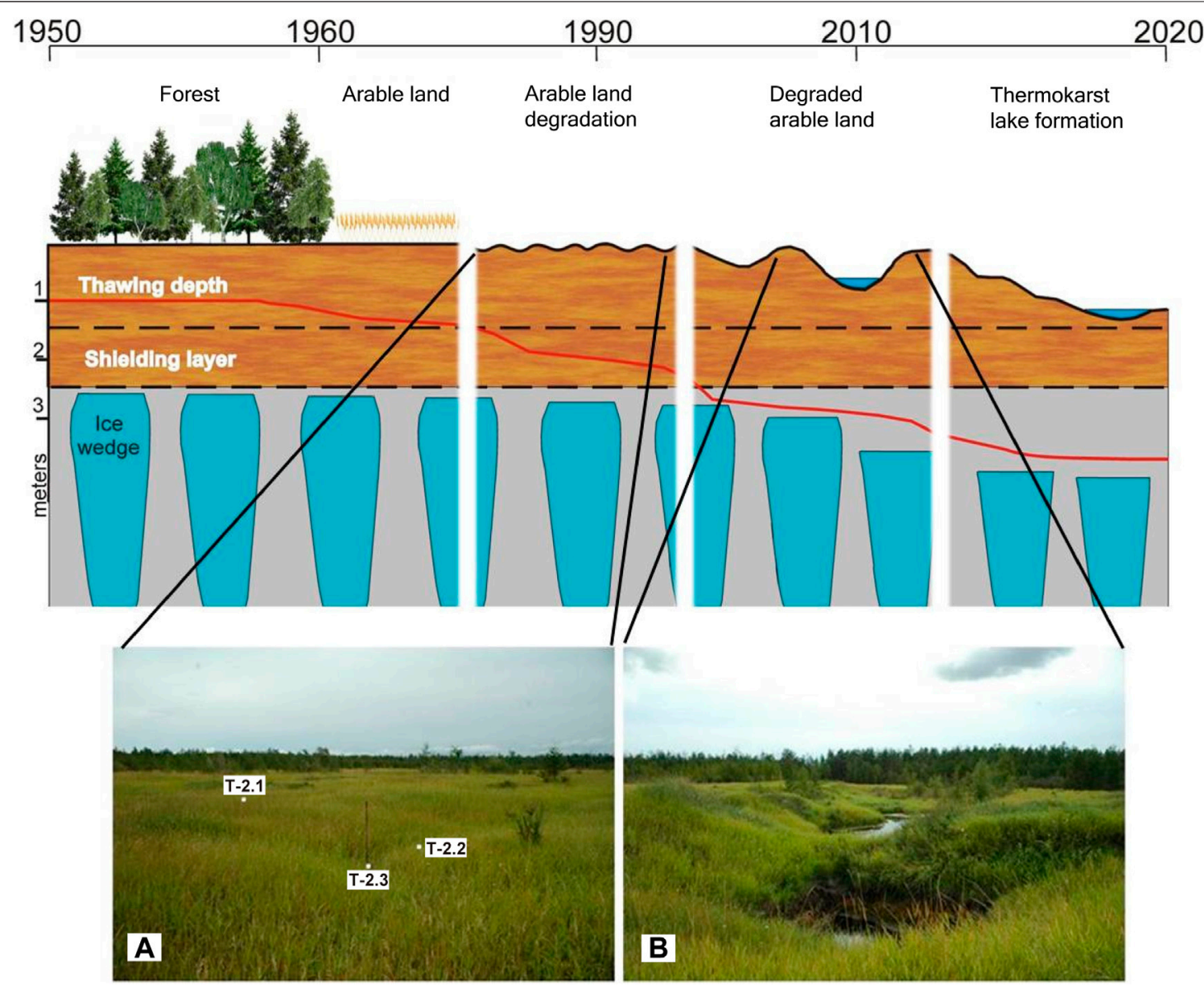

FIGURE 5 | Development scheme, general view, and location of studied soil pits on the former arable field (Tabaga site) abandoned in the 1970s-1980s and subjected to thermokarst with the formation of $\mathbf{( A )}$ byllar and $\mathbf{( B )}$ dyuedya microtopography.

to the Walkley-Black method and involves the combustion of the organic matter with a $1: 1$ mixture of $0.14 \mathrm{M} \mathrm{K}_{2} \mathrm{Cr}_{2} \mathrm{O}_{7}$ and concentrated $\mathrm{H}_{2} \mathrm{SO}_{4}$ at $150^{\circ} \mathrm{C}$ for $20 \mathrm{~min}$ and titration with ferrous sulfate solution or colorimetric measurement on a SPECOL 211 spectrometer at $590 \mathrm{~nm}$ (van Reeuwijk, 2002).

Particle-size distribution analysis for Tabaga site was applied to the fine earth fraction $(<2 \mathrm{~mm})$. After ultrasound dispersion and sieving, oxidation of organic matter by $\mathrm{H}_{2} \mathrm{O}_{2}$, removal of carbonates by $\mathrm{HCl}$, and shaking with dispersing agent $\left(\mathrm{NaPO}_{3}+\right.$ $\mathrm{Na}_{2} \mathrm{CO}_{3}$ ), the sand fraction was separated from other fractions using a $63-\mu \mathrm{m}$ sieve. The clay $(<2 \mu \mathrm{m})$ and silt $(2-63 \mu \mathrm{m})$ fractions were determined by pipette method (van Reeuwijk, 2002). The same pretreatment was applied to samples from the Churapcha site. However, the fractions were determined according to the Russian system of particle-size classes: sand, $1-0.05 \mathrm{~mm}$; silt, $0.05-0.001 \mathrm{~mm}$; and clay, $<0.001 \mathrm{~mm}$. In this study, the original data on the Churapcha site are recalculated to the international scale (2000-63-2 $\mu \mathrm{m})$ using Shein's model (Shein, 2009).

The determination of the cation exchange capacity and exchangeable bases was conducted in accordance with the methodological guidance of "Procedures for Soil Analyses" (van Reeuwijk, 2002) by the ammonium acetate method using a programmable mechanical vacuum extractor (Model 24VE). In the non-carbonate and non-saline soil samples, the exchangeable bases were displaced by $1 \mathrm{M} \mathrm{NH}_{4} \mathrm{OAc}$ solution (pH 7.0), sample weight $2.5 \mathrm{~g}$ for mineral specimens and $1 \mathrm{~g}$ for organic specimens. In saline and calcareous soils, the preliminary washing of the samples with $80 \%$ ethanol was performed. Then, exchangeable bases were displaced by $1 \mathrm{M}$ $\mathrm{NH}_{4} \mathrm{OAc}$ ( $\mathrm{pH}$ 8.2). The cation exchange capacity (CEC) was determined using a solution of $0.9 \mathrm{M} \mathrm{NaOAc}(\mathrm{pH}$ 8.2). The concentrations of $\mathrm{Ca}^{2+}, \mathrm{Mg}^{2+}, \mathrm{K}^{+}$, and $\mathrm{Na}^{+}$in the solution were measured on an atomic emission spectrometer with inductively coupled plasma Spectro CirosCCD (Germany, Spectro Analytical Instruments $\mathrm{GmbH}$ ).

\section{RESULTS}

The whole sets of morphological, micromorphological, and analytical data for the Tabaga and Churapcha sites were presented in two guidebooks (Desyatkin et al., 2013, 2017). For the Tabaga site, this information is accessible on the Web 


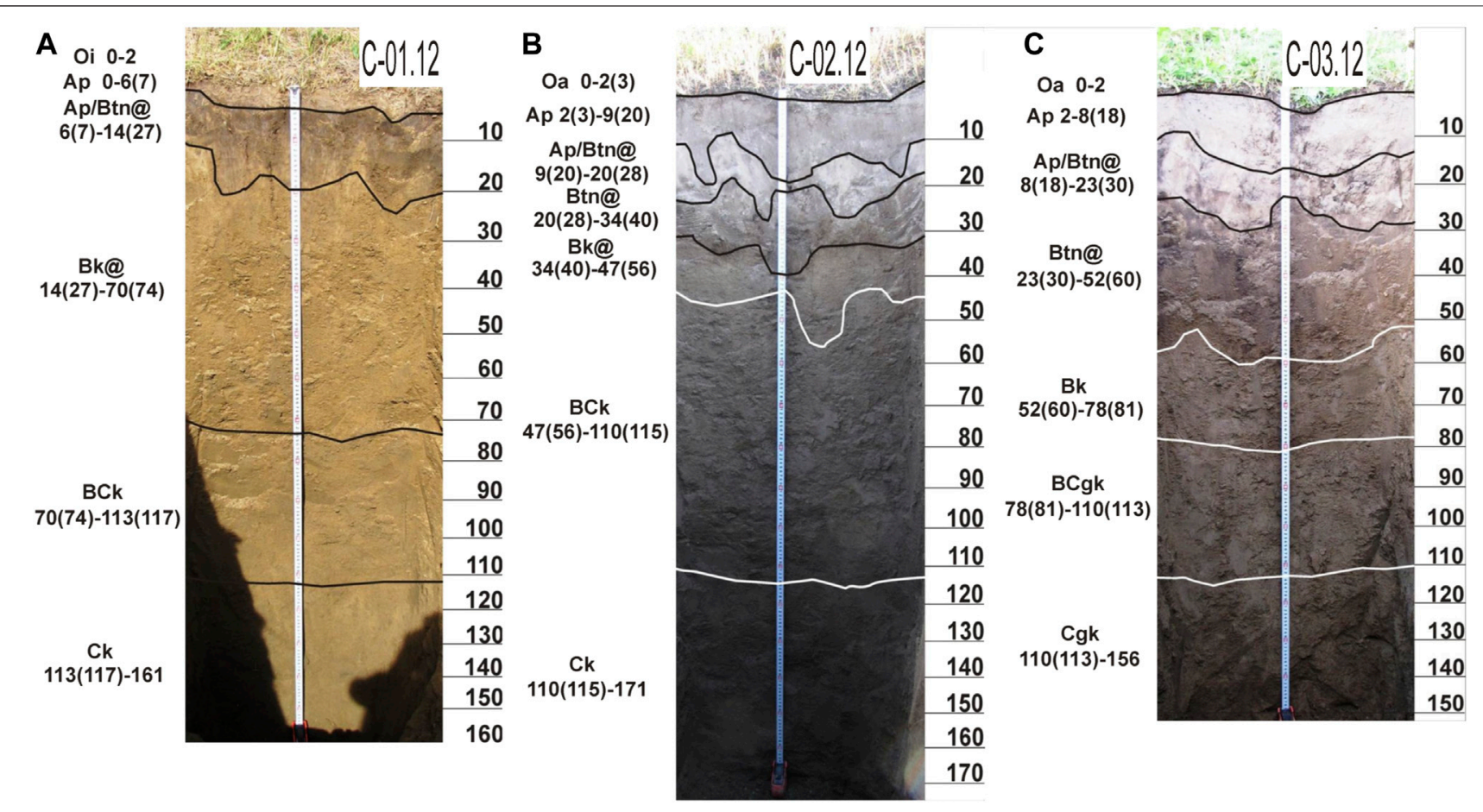

FIGURE 6 | Horizonation of soil profiles studied at the Churapcha site: (A) top of byllar, pit C-01-12; (B) slope of byllar, pit C-02-12; and (C) microlow between byllars, pit C-03-12.

(https://www3.ls.tum.de/fileadmin/w00bds/boku/downloads/ wrb/Guide_Sakha_final.pdf).

\section{Field Data. Soil Profiles}

Churapcha site. A general view of the studied soil profiles and their horizonation is presented in Figure 6. Brief descriptions of the specificity of soil morphology are given below.

Pit C-01-12 (61 $\left.59.136^{\prime} \mathrm{N}, 132^{\circ} 29.807^{\prime} \mathrm{E}\right)$ was examined on the top of a byllar within the abandoned arable field $1.5 \mathrm{~km}$ northwest of the town of Churapcha on July 17, 2012. The soil was developed under steppe herbs (Artemisia commutata, Vicia cracca L., Potentilla anserina L., Taráxacum officinále, etc.) covering about $45-50 \%$ of the surface; cryogenic cracks of up to $10 \mathrm{~cm}$ in width were seen on the soil surface. The parent material was represented by calcareous loesslike loam. From the depth of $161 \mathrm{~cm}$, the parent material was in the frozen state.

In the WRB system, this soil can be classified as a Calcic Solonetz (Loamic, Turbic) with the profile Oi-Ap-Ap/Btn@ - Bk@-BCk-Ck in the FAO system of horizon designation. This profile, as well as the other two studied profiles, cannot be classified as Cryosols in spite of the presence of frozen horizons. This is because the maximum thawing depth (in September) is deeper than $2 \mathrm{~m}$.

Note the presence of a thin litter layer $(\mathrm{O})$ consisting of weakly decomposed residues of herbs on the mineral soil surface. The former plow (Ap) horizon is differentiated; in its upper part, the modern humus (Ap) horizon of gray color with brownish tint is formed. The lower part of the plow horizon is mixed by cryogenic processes with the strongly compacted subsoil now representing a solonetzic (Btn) horizon. Fragments of the plowpan are marked by the darkest color in the profile. This horizon (Ap/Btn@) is dissected by cryogenic fissures filled with tongues and pockets of humified material. The underlying carbonate-accumulative (Bk@) horizon represents effervescing loesslike loam of yellowish (pale brown) color with a total thickness of $47-56 \mathrm{~cm}$; this horizon is considerably thicker than in the other two soil pits. The transitional $\mathrm{BCk}$ horizon with residual carbonates represents a slightly dry, dense, strongly effervescing silt loam with coarse angular blocky structure; its thickness is up to $43 \mathrm{~cm}$. The parent material (Ck) is a grayish, wet, moderately compact, calcareous silt loam with coarse blocky structure. The thawing depth on the day of the soil description was $161 \mathrm{~cm}$; the ice content in the underlying seasonally frozen layer (Ck) was low.

Pit C-02-12 (61 $\left.59.136^{\prime} \mathrm{N}, 132^{\circ} 29.807^{\prime} \mathrm{E}\right)$ was described $4 \mathrm{~m}$ away from pit C-01-12 on the slope of southwestern aspect of the same byllar on July 17, 2012. Steppe herbs with a higher participation of Potentilla anserina L. and grasses Poa praténsis L. and Elytrígia répens L. covered $65-70 \%$ of the surface. The soil developed from the same parent material (calcareous loesslike loam); the thawing depth reached $171 \mathrm{~cm}$.

The soil had the following horizonation: Oa-Ap-AEp/ Btn@-Btn@-Bk@-BCk-Ck-Ckf. It was also classified as a Calcic Solonetz (Albic, Loamic, Turbic).

The uppermost brown-colored horizon of this soil is densely penetrated by roots and contains abundant plant residues of different decomposition degrees. As a result of deformation of the surface microtopography, this soil is now in a relatively welldrained slope position, which could enhance leaching processes 
and the removal of labile fractions of the organic matter from the former plow horizon. This horizon acquired a light gray color with brownish tint. The underlying solonetzic (Btn) horizon has a thickness of about $12-14 \mathrm{~cm}$ [from $20(28)$ to $34(40) \mathrm{cm}$ ] and is less disturbed by the cryogenic processes in comparison with the soil on the top of the byllar. This horizon clearly differs from the whitish overlying layer and from the underlying carbonateaccumulative (Bk) horizon. The transitional BCk horizon has the greatest thickness $(42 \mathrm{~cm})$ among the three studied soils. The thawing depth in this soil reached $171 \mathrm{~cm}$.

Pit C-03-12 (61 $\left.59.136^{\prime} \mathrm{N}, 132^{\circ} 29.807^{\prime} \mathrm{E}\right)$ was examined on the same day in the bottom of the microlow between neighboring byllars, $3 \mathrm{~m}$ from pit C-02-12. This soil developed under mesophytic steppe herbs with a predominance (up to 70\%) of Potentilla anserina L.; almost the entire surface (90-95\%) was covered by plants. The parent material-calcareous loesslike loam-was in the frozen state from the depth of $156 \mathrm{~cm}$.

The soil profile consisted of the following horizons: Oa-Ap-AEp/Btn@-Btn@-Bk-BCgk-Cgk. It was classified as a Calcic Stagnic Solonetz (Albic, Loamic, Turbic).

In this soil, the illuvial (solonetzic) Btn horizon is found somewhat deeper and has a greater thickness than that in the soils of the byllar. The light-colored zone of eluviation is also thicker. Thus, the upper- and middle-profile horizons are somewhat extended under the impact of the subsidence of the lower horizons because of the melting of the ice wedge found below the soil profile. The thickness of the middle-profile carbonate-accumulative (Bk) horizon is reduced. The lower part of the profile is marked by the presence of stagnic features.

The depth to the horizon of parent material (Ck) with minimal indications of pedogenetic transformation in the three studied profiles is approximately the same (about $110 \mathrm{~cm}$ ). In general, though the sequences of the major horizons in the three studied profiles look similar, their thicknesses are different. The thickness of the upper part of the profile with the zones of eluviation and illuviation of substances is somewhat greater on the slope of byllar than on its top and gains maximum in the soil of the microlow between neighboring byllars. The soil on the top of byllar was formally classified as Solonetz because of the high percentage of sodium in the soil exchange complex (see below). However, weak differentiation in clay makes it closer to Sodic Cambisols.

Tabaga site. The trench examined at the Tabaga site $\left(61^{\circ} 48^{\prime} 55.7^{\prime \prime}\right.$ $\mathrm{N}, 129^{\circ} 31^{\prime} 51.5^{\prime \prime} \mathrm{E}$ ) included three reference soil profiles (Figure 7). In 2013, they were demonstrated to the participants of the WRB "Mammoth" tour (Desyatkin et al., 2013). After discussion in the field and careful examination of field and laboratory data, the classification position of these soils in the WRB system given by Desyatkin et al.(2013) was specified by field tour participants, and in this study, we use the soil names approved by them.

The surface microtopography at the Tabaga site was less pronounced than at the Churapcha site, and the size of thermokarst mounds (byllars) and microlows between them was somewhat smaller. Steppe herbs covered almost $100 \%$ of the surface and had a more mesophytic character in the microlows. However, despite more homogeneous surface conditions, the differentiation of the soil profiles within the studied trench was very distinct (Figure 7).
Pit T-2.1 (profile 2-1 in the guidebook) characterized a part of the trench crossing the top of byllar. It had the following horizonation: A-Bwk-BCkg@-BCkg-2BCkg. The humus horizon (former plow layer) had a brownish-black color, silt loamy texture, and fine subangular blocky structure. Its lower boundary was abrupt and slightly wavy. The middle-profile horizons (Bwk, BCkg@, BCkg) were characterized by dull yellow to yellowish-gray color, platy to subangular blocky structure, some horizontal layering, and distinct effervescence because of the abundance of dispersed calcite grains and few fine ( $\mathrm{d} \sim 2 \mathrm{~mm}$ ) soft carbonate nodules (in the Bwk horizon). It was classified as Stagnic Cambisol (Sodic, Turbic, Pisocalcic, Episiltic).

Pit T-2.2 (profile 2-3 in the guidebook) characterized the soil on the slope of adjacent byllar. Its horizonation (A-E-Btn-Bk-BCk) displayed a pronounced differentiation into the eluvial and clay-illuvial parts. This profile was less cryoturbated, and the depth of effervescence $(60 \mathrm{~cm})$ occupied an intermediate position. It was classified as Calcic Mollic Solonetz (Albic, Siltic, Turbic).

Pit T-2.3 (profile 2-2 in the guidebook) characterized the soil in the microlow with the following horizonation: A-AE@EA@-E@-EB-Btn-BCk. It had a much thicker $(30-46 \mathrm{~cm})$ and darker humus horizon, distinct features of cryoturbation in the middle-profile horizons, and a pronounced differentiation into the eluvial (AE@-E@) and clay-illuvial (EB@-Btn) parts. The depth of effervescence was much deeper $(120 \mathrm{~cm})$. It was classified as Mollic Hyposalic Solonetz (Glossalbic, Humic, Siltic, Turbic).

Descriptions of these soil profiles at the initial stage of arable land degradation were given by Gavril'ev et al. (2005). Our research attests to the acceleration of transformation processes.

In general, the patterns of the lateral differentiation of the soils by the elements of byllar microtopography at the two studied sites have much in common. The least differentiated soil profiles with a shallow depth of effervescence are observed on the tops of byllars. The thickness of the humus horizon noticeably increases in the soils of the microlows. The eluvial-illuvial differentiation enhances on the slopes of byllars and in the microlows between them. At both sites, it has led to the appearance of the bleached eluvial (E) horizon. At the Churapcha site, stagnic features in the soil profiles are clearly pronounced in the microlow. At the Tabaga site, they are observed in the lower part of the soil under the top of the byllar and are absent in the soils on its slope and in the microlow, which were excavated to a shallower depth. It is probable that they should appear in deeper horizons. Note, however, that the redistribution of soil water by the elements of the less pronounced byllar microtopography at the Tabaga site should be less active than that at the Churapcha site.

\section{Laboratory Data. Bulk Density, Soil Reaction, Particle-Size Distribution, and Organic Carbon Content}

Laboratory data on soil reaction $(\mathrm{pH})$, organic carbon content, particle size distribution, and bulk density (Table 1) are informative indicators of soil transformation during the 


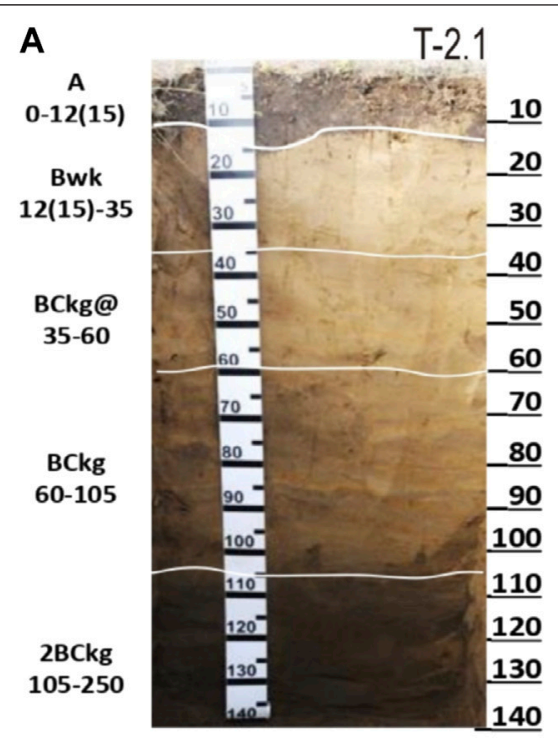

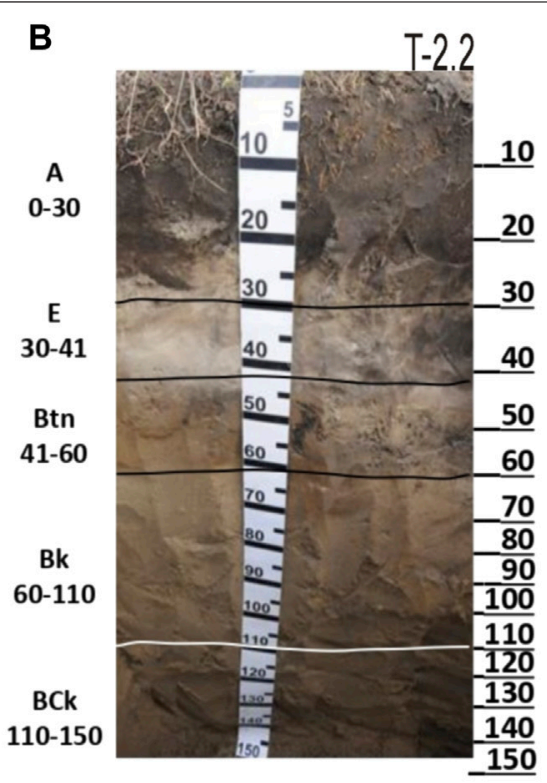

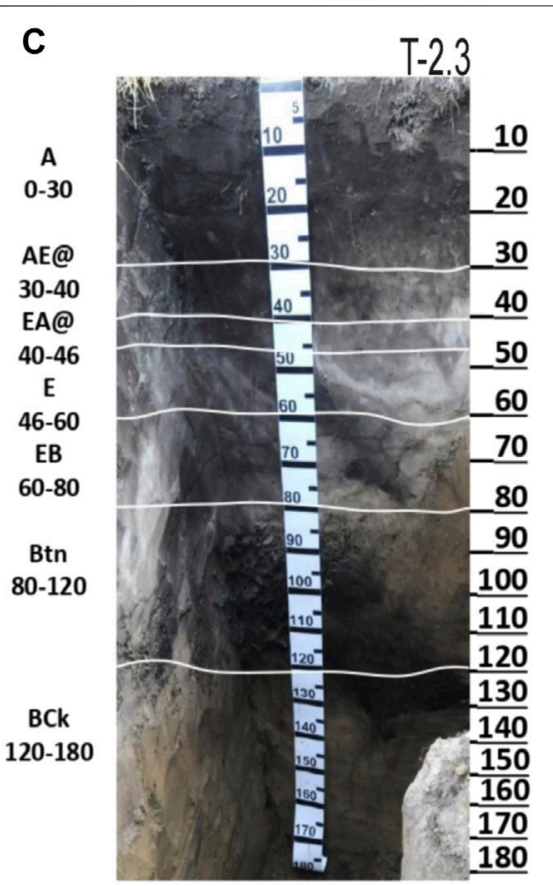

FIGURE 7 | Horizonation of soil profiles studied at the Tabaga site: (A) top of byllar, pit T-2.1; (B) slope of byllar, pit T-2.2; and (C) microlow between byllars, pit T-2.3.

development of thermokarst processes. We also use information on the proportion of sodium and magnesium cations in the sum of exchangeable cations.

Soil reaction. As can be seen from Table 1, the $\mathrm{pH}$ values of the soils on the top of byllars at both sites indicate a very strongly alkaline reaction throughout the profile $\left(\mathrm{pH}_{\text {water }}>9.5\right)$. Slightly lower $\mathrm{pH}$ values characterize the soils on the slopes of byllars, but a different distribution of $\mathrm{pH}$ values is observed in the soils of microlows, in which the upper horizons have a neutral reaction because of leaching of carbonates and, evidently, the absence (or low content) of exchangeable sodium. In the soil of the microlow at the Churapcha site, a general decrease in alkalinity is observed throughout the soil profile. In the analogous soil at the Tabaga site, where the redistribution of moisture by the elements of the microtopography is less pronounced (because of their smaller sizes), the soil reaction in the deep part of the profile reaches strongly alkaline values. Microlows are the areas of concentration of surface runoff, and thermokarst-driven loosening of the lower part of the soil at the Churapcha site (see below) enhances infiltration of water with dissolved substances and its withdrawal from the soil profile into thermokarst voids (Figure 8).

The organic carbon content in the soil profiles is generally very low (0.4-0.6\%), except for the topmost thin organic horizons (Churapcha site) and humus horizons. The maximum $\mathrm{C}_{\text {org }}$ content in the humus horizons at both sites is observed in the soils of microlows $(2.77 \%$ at the Churapcha site and $2.95 \%$ at the Tabaga site). The uneven distribution of $\mathrm{C}_{\text {org }}$ in the soil of the microlow at the Tabaga site is noted. A local maximum (2.40\%) at the depth of 40-46 cm (pit T-2.3., EA@ horizon) is explained by the influence of cryoturbation with a deep penetration of humus tongue.

The proportion of sodium and magnesium cations in the sum of exchangeable cations is indicative of the possibility of manifestation of the solonetzic process. Soils of the Churapcha site have more sodium and magnesium in their exchange complex than soils of the Tabaga site. However, the Btn horizons of soils at both sites have the high content of sodium and magnesium cations in their exchange complex.

Particle-size distribution data attest to a coarser texture and higher content of sand fractions in the soils of the Tabaga site. The contents of clay and silt fractions in the soils of the Churapcha site vary within $30-56 \%$ with clear maximums of the clay content in the clay-illuvial (Btn) horizons. At the Tabaga site, silt fractions predominate throughout the soil profiles, except for the BCkg@ horizon of pit T-2.1 with a predominance $(44-51 \%)$ of sand fractions. Similar to the Churapcha site, maximum values of the clay content are observed in the Btn horizon of the soil developed in the microlow. Thus, the processes of clay illuviation are most pronounced in this geomorphic position.

Bulk density is found to be dynamic. Thus, on cultivated fields, freshly tilled soil is most friable; then, it compacts, and its bulk density gradually comes to an equilibrium state. As it is known, during thermokarst transformation of soils under the impact of melting of subsurface ice wedges, soil subsidence takes place in some areas (above ice wedges), whereas other areas keep their former position (byllars or thermokarst mounds). By studying the bulk density of the soils on different elements of the microtopography, it is possible to determine the effect of 
TABLE 1 | Laboratory data on soil samples from the Churapcha and Tabaga key sites.

\begin{tabular}{|c|c|c|c|c|c|c|c|c|}
\hline \multirow[t]{2}{*}{ Pit no. } & \multirow[t]{2}{*}{ Horizon } & \multirow[t]{2}{*}{ Depth, cm } & \multirow[t]{2}{*}{$\mathrm{pH}_{\mathrm{H} 2 \mathrm{O}}$} & \multirow[t]{2}{*}{$\mathrm{C}_{\text {org }}, \%$} & Clay & Silt & Sand & \multirow{2}{*}{$\begin{array}{c}\text { Bulk } \\
\text { density, } \\
\mathbf{g ~ c m}^{-3}\end{array}$} \\
\hline & & & & & \multicolumn{3}{|c|}{$\%$} & \\
\hline \multicolumn{9}{|c|}{ Churapcha key site } \\
\hline \multirow[t]{6}{*}{ C-01-12, top of byllar } & $\mathrm{Oi}$ & 0-2 & 8.16 & 13.61 & - & - & - & 0.21 \\
\hline & Ap & 2-6 (7) & 9.5 & 1.88 & 29 & 59 & 12 & 1.19 \\
\hline & Ap/Btn@ & $6-14(27)$ & 9.69 & 0.92 & 31 & 62 & 7 & 1.38 \\
\hline & Bk@ & $14(27)-70$ & 9.66 & 0.43 & 30 & 58 & 12 & 1.31 \\
\hline & BCk & $70-113$ & 9.6 & 0.67 & 30 & 56 & 14 & 1.27 \\
\hline & Ck & $113-161$ & 9.54 & 0.82 & 30 & 59 & 11 & 1.53 \\
\hline \multirow[t]{8}{*}{ C-02-12, slope of byllar } & $\mathrm{Oa}$ & $0-2(3)$ & 7.65 & 16.31 & - & - & - & 0.25 \\
\hline & Ap & $2-9(20)$ & 9.15 & 1.39 & 26 & 64 & 10 & 1.27 \\
\hline & AEp/ & $9-20(28)$ & 8.69 & 1.19 & 13 & 70 & 18 & 1.46 \\
\hline & Btn@ & & & & & & & \\
\hline & Btn@ & 20-34 (40) & 9.54 & 1.29 & 36 & 54 & 10 & 1.24 \\
\hline & Bk@ & $34-47(56)$ & 9.64 & 0.49 & 35 & 57 & 8 & 1.49 \\
\hline & BCk & $47-110(115)$ & 9.6 & 0.42 & 29 & 62 & 9 & 1.49 \\
\hline & Ck & 110-171 & 9.06 & 0.46 & 30 & 60 & 10 & 1.44 \\
\hline \multirow[t]{7}{*}{ C-03-12, microlow } & $\mathrm{Oa}$ & $0-2$ & 6.13 & 21.19 & - & - & - & 0.31 \\
\hline & Ap & $2-8(18)$ & 6.19 & 2.77 & 20 & 66 & 15 & 1.25 \\
\hline & $\begin{array}{l}\text { AEp/ } \\
\text { Btn@ }\end{array}$ & 8-23 (30) & 7.34 & 1.51 & 25 & 66 & 9 & 1.39 \\
\hline & Btn@ & 23-52 (60) & 8.65 & 0.73 & 41 & 51 & 8 & 1.31 \\
\hline & Bk & 52-78 (81) & 8.9 & 0.45 & 32 & 61 & 8 & 1.31 \\
\hline & BCgk & $78-110(113)$ & 8.96 & 0.53 & 31 & 60 & 9 & 1.36 \\
\hline & Cgk & $110-156$ & 8.92 & 0.56 & 30 & 61 & 9 & 1.04 \\
\hline \multicolumn{9}{|c|}{ Tabaga key site } \\
\hline \multirow[t]{5}{*}{$\mathrm{T}-2.1$, top of byllar } & A & 0-12 (15) & 8.80 & 1.64 & 6 & 60 & 34 & 1.27 \\
\hline & Bwk & $12(15)-35$ & 9.30 & 0.33 & 9 & 59 & 32 & 1.54 \\
\hline & BCkg@ & 35-60 & 9.75 & 0.28 & 11 & 38 & 51 & 1.50 \\
\hline & BCkg & $60-105$ & 9.75 & 0.42 & 12 & 44 & 44 & 1.42 \\
\hline & 2BCkg & $105-250$ & 9.60 & 0.42 & 16 & 57 & 27 & N.d. \\
\hline \multirow[t]{6}{*}{$\mathrm{T}-2.2$, slope of byllar } & $\mathrm{A} 1$ & $0-22$ & 7.35 & 2.01 & 15 & 53 & 32 & 1.48 \\
\hline & A2 & $22-30$ & 8.55 & 1.66 & 15 & 53 & 32 & 1.49 \\
\hline & $E$ & $30-41$ & 8.55 & 0.33 & 6 & 56 & 38 & 1.58 \\
\hline & Btn & $41-60$ & 9.45 & 0.65 & 15 & 53 & 32 & 1.64 \\
\hline & $\mathrm{BK}$ & $60-110$ & 9.55 & 0.59 & 18 & 53 & 29 & N.d. \\
\hline & $\mathrm{BCK}$ & $110-150$ & 9.50 & 0.29 & 13 & 45 & 42 & N.d. \\
\hline \multirow[t]{10}{*}{ T-2.3, microlow } & $\mathrm{A} 1$ & $0-4$ & 6.95 & 2.95 & 16 & 50 & 34 & 1.21 \\
\hline & $\mathrm{A} 2$ & 4-20 & 7.20 & 1.96 & 16 & 51 & 33 & 1.55 \\
\hline & A3 & $20-30$ & 7.50 & 2.23 & 18 & 53 & 29 & 1.34 \\
\hline & AE@ & $30-40$ & 7.70 & 1.67 & 16 & 53 & 31 & 1.38 \\
\hline & EA@ & $40-46$ & 8.70 & 2.40 & 11 & 55 & 34 & N.d. \\
\hline & E & $46-60$ & 8.65 & 0.75 & 8 & 54 & 38 & 1.47 \\
\hline & EB & 60-80 & 7.75 & 1.34 & 12 & 58 & 30 & 1.13 \\
\hline & Btn1 & 80-100 & 8.80 & 0.53 & 20 & 51 & 29 & 1.60 \\
\hline & Btn2 & $100-120$ & 9.00 & 0.47 & 20 & 44 & 36 & N.d. \\
\hline & BCk & $120-180$ & 9.55 & 0.54 & 16 & 47 & 37 & N.d \\
\hline
\end{tabular}

degradation of subsurface ice on the spatial and vertical differentiation of bulk density values.

Bulk density values of the soil on the top of byllar at the Churapcha site are generally typical of the permafrost-affected solonetzic pale soils (in Russian soil classification system) or Cambic Turbic Cryosols (Aric, Loamic, Sodic). A thin [0-6 (7) $\mathrm{cm}$ ] gray-humus horizon forming in place of the former plow layer has the bulk density of $1.19 \mathrm{~g} / \mathrm{cm}^{3}$ (Table 1). Below, there is a dense subsurface eluvial-solonetzic horizon representing the former plowpan (Ap/Btn@) with an increased bulk density. In the underlying calcareous $\mathrm{Bk}$ and $\mathrm{BCk}$ horizons, bulk density is about $1.3 \mathrm{~g} / \mathrm{cm}^{3}$. It increases in the lowermost suprapermafrost horizon (Ck) up to $1.53 \mathrm{~g} / \mathrm{cm}^{3}$. In general, analogous bulk density values are typical of native pale soils (Cambic Turbic Cryosols) under taiga vegetation (Elovskaya and Konorovskii, 1978). The reduction in the thickness of the former plow layer may be 


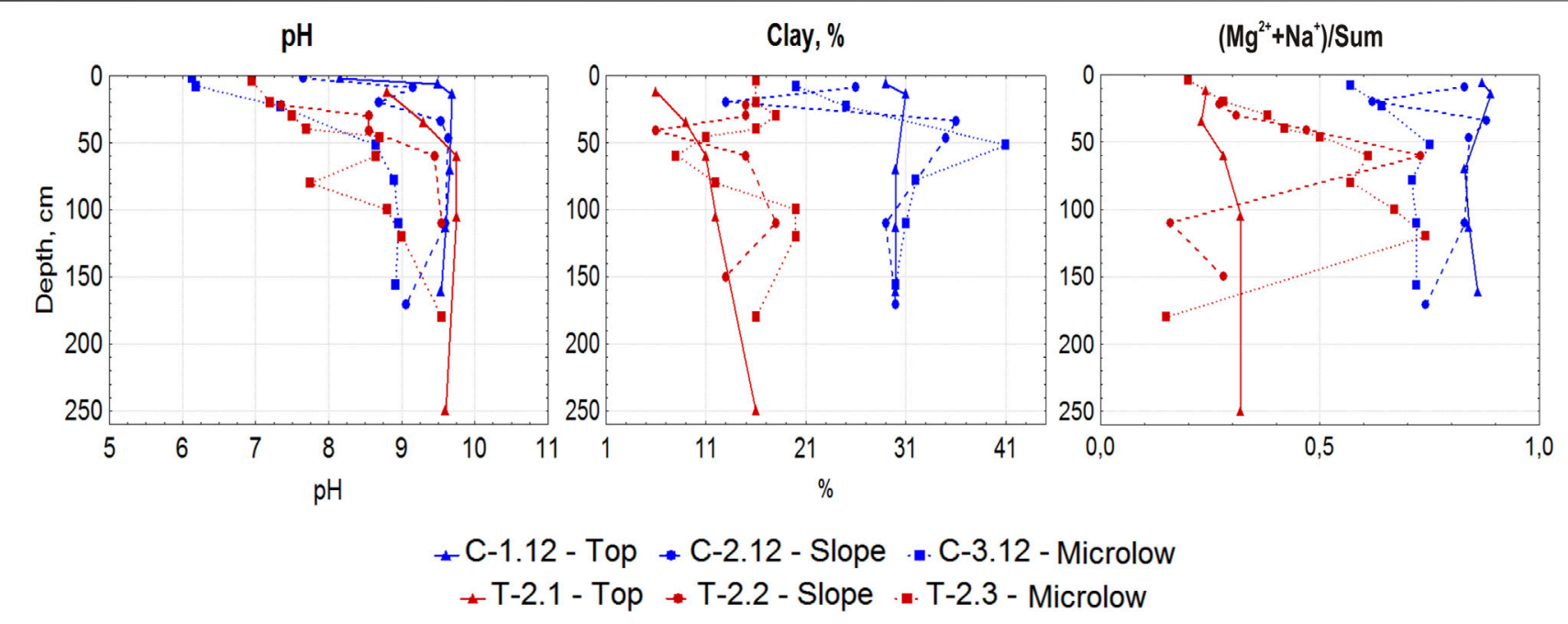

FIGURE 8 | Distribution of $\mathrm{pH}$ values, clay content, and the portion of $\left(\mathrm{Na}^{+}+\mathrm{Mg}^{2+}\right)$ in the exchange complex of soils studied at the Churapcha (blue lines) and Tabaga (red lines) sites.

due to a combination of factors, such as the initially not deep plowing and the action of water erosion under conditions of terrain deformation because of thermokarst development in the recent decades.

As a result of subsidence of the soil on the slope of the byllar, a significant rearrangement of bulk density values has taken place. The compaction of the surface (former plow) and subsurface (subplow) horizons occurs because of the development of a relatively thick soddy horizon in the absence of its mechanical loosening and strengthening of the solonetzic properties in the former subplow layer due to the increased washing of the upper soil layer. At the same time, the bulk density of the underlying solonetzic horizon $(20-40 \mathrm{~cm})$ somewhat decreases due to the removal of soluble salts from the upper horizons. The genetic horizons in the lower half of the soil profile on the microslope of the byllar undergo compaction, which may be related to the vertical compression of the soil upon subsidence of the tightly bound upper soil horizons in local areas after the considerable soil subsidence in the microlow because of ice melting.

The melting of ice wedges that serve as the basement for overlying sediments in the microlows leads to the most considerable subsidence of the soil in the microlow. This subsidence also involves some soils on the adjacent slopes. The bulk density of the soil in the microlow in the upper meter does not change much in comparison with the soil of the byllar. At the same time, the lower part of the soil of the microlow is subjected to a strong decompaction; its bulk density is only $1.04 \mathrm{~g} / \mathrm{cm}^{3}$. Such a strong loosening of this soil is explained by the downward collapse of the lowermost soil horizons following the collapse of the ice-rich permafrost-protective transient layer overlying the melting ice wedge under the action of heat wave with positive soil temperatures because of climate warming.

At the Tabaga site, bulk density values are generally somewhat higher. A tendency for soil loosening is only observed in the upper part of the humus horizon. Below, bulk density values tend to increase to reach maximum values (up to $1.64 \mathrm{~g} / \mathrm{cm}^{3}$ ) in the solonetzic (Btn) horizons. We have not found a decrease in the bulk density of the lower horizons in the soil of the microlow (pit $\mathrm{T}-2.3$ ). It is probable that the effect of the soil loosening above melting ice wedge can be observed in the deeper part of this soil, or even beyond the soil profile.

\section{DISCUSSION}

The results obtained from this study attest to considerable variation of soil properties following the differentiation of surface topography owing to the development of thermokarst on the arable field.

It is known for at least 70-80 years that after development of permafrost-affected soils into cropland after clear-cutting and wildfires, the permafrost table descends downwards (Péwé, 1954; Tomirdiaro, 1978; Yoshikawa et al., 2002; Iwahana et al., 2005; Shur and Jorgenson, 2007). However, the same studies stated that after returning to the natural environment, the permafrost table rises up again. The experience of geocryologists in Central Yakutia showed that the permafrost table did not move upward after the abandonment of formerly arable land, and this was related to climate warming (Gavriliev et al., 2001; Gavriliev, 2008; Iijima et al., 2010).

Our studies confirm this statement. It is probable that, in the current era, we are observing, the transition of "ecosystem-driven permafrost" to "climate-driven ecosystem-protected permafrost" (according to Shur and Jorgenson, 2007) in Central Yakutia. This means an irreversible trend of permafrost degradation in the areas of former cropland.

The progressing development of thermokarst processes predetermines the change in the character of soil formation and in the classification status of permafrost-affected soils. The 
soils studied on the top of byllars represent postagrogenic soils, or the remains of the formerly cultivated soils, in which the surface plow and the underlying subplow horizons had been formed in several decades of the soil cultivation. The beginning of the soil cultivation dates back to the mid-1960s, when the native larch-birch forests (charany) were cleared out, and arable fields were organized in their place (Desyatkin, 2004).

The soils of these forests in their natural state were investigated by A. A. Krasyuk, who found that permafrost-affected solods [ Luvic Turbic Cryosols (Albic, Loamic)] develop under birch groves and podzolized solonetzic soils ( Natric Turbic Cryosols (Albic, Loamic)) develop under larch stands (Krasyuk and Ognev, 1927). Later, V.G. Zol'nikov (1954) and L.G. Elovskaya (1964) considered the soils under larch forests as soddy forest soils [ Mollic Turbic Cryosols (Loamic)] or as permafrost-affected pale (palevye) soils [ Cambic Turbic Cryosols (Loamic, Humic, Sodic)]. Under forest vegetation, the thawing depth in these soils was less than $2 \mathrm{~m}$, and there were clear features of cryoturbation in their profiles, so they fitted the concept of Cryosols in the WRB (IUSS Working Group WRB, 2015). Taking into account these classical studies of experts in Yakutian soils and the results obtained from this study, we suppose that "permafrost-affected solonetzic pale soils" [Cambic Turbic Cryosols (Sodic, Luvic)] in the case of Churapcha site and "permafrost-affected solonetzic dark pale soils" [Mollic Turbic Cryosols (Sodic, Luvic)] in the case of Tabaga site predominated within currently degrading arable fields around Churapcha and Tabaga, respectively. In the course of their cultivation, the surface plow and subplow horizons were formed in the soil profiles. Unfortunately, we currently have no reliable information on the spatial variation of relevant soil features under intact forests. These data should be gained at the next stage of the study. This is particularly important for correct evaluation of the rates of soil changes during the agrogenic (arable farming) and postagrogenic (cessation of soil tillage because of thermokarst development) stages.

After the abandoning of the fields and the cessation of tillage, a thin litter layer composed of mainly weakly decomposed remains of herbs has formed on the soil surface. The former plow horizon has been transformed into the gray-colored humus horizon. The subplow layer has been mixed by cryoturbation with the underlying solonetzic horizon containing fragments of the former plowpan marked by the darkest color. This layer is also marked by the most distinct cryogenic fissures, along which the tongues of humified material from the upper horizon penetrate deeper into the soil. Such a profile was examined on the top of byllar at the Churapcha site.

This "normal" pattern of the postagrogenic soil development was complicated by the progressing thawing of permafrost because of the removal of the protecting cover of forest vegetation and forest litter and warming of the climate. At present, the maximum thawing depth exceeds $2 \mathrm{~m}$ at both study sites, and the soils do not fit the definition of Cryosols, though the soils in winter freeze down to the permafrost table. When the seasonal thawing depth reached the surface of underlying ice wedges, their melting began, which caused a sharp differentiation of the surface microtopography and the appearance of residual mounds (byllars) between the polygonal networks of hollows (microlows) above the ice wedges. In turn, this triggered the differentiation of the soil properties by the elements of the newly formed microtopography.

It is evident that the soil on the top of byllars (pits C-01-12 and $\mathrm{T}-2.1$ ) receives the minimum amount of atmospheric moisture. This convex landform does not favor the accumulation of snow. It is probable that the surface soil horizon could be somewhat eroded, so that the thickness of the former plow layer has decreased. This is clearly manifested in profile T-2.1. Leaching processes are not active, and the soil is characterized by the highest $\mathrm{pH}$ values attesting to the presence of exchangeable sodium.

The soil on the microslope of byllars (pits C-02-12 and T-2.2) receives more moisture with surface runoff. Its upper part is characterized by somewhat lower $\mathrm{pH}$ values. However, deep vertical infiltration is impeded by the presence of the dense solonetzic horizon. It can be supposed that lateral soil water flow toward the adjacent microlow takes place above this horizon. Note that the natric horizon and the upper boundary of the calcic horizon (the line of effervescence) in this soil are found somewhat deeper.

The soil of the microlows (pits C-03-12 and T-2.3) between neighboring byllars receives the maximum amount of water due to the accumulation of snow and surface and soil runoff from the adjacent slopes. Soluble salts and exchangeable sodium are removed from their upper part with the neutral soil reaction. At the same time, the former solonetzic Btn horizon is still preserved in the profile, which is marked by the increased bulk density. Note a considerable decrease in bulk density values in the lower part of the profile in pit C-03-12, which can be explained by the soil loosening related to the thawing of ice-rich transient layer and the appearance of hollow space under the soil profile owing to the ice wedge melting. This should favor deep water infiltration. At the Tabaga site, the soil of the microlow is characterized by the maximum accumulation of organic carbon at a considerable depth, which may be due to soil erosion at the top of the byllar, cryoturbation, and humus migration into the Btn horizon.

Thus, dynamic indicators (bulk density, $\mathrm{pH}$, and organic carbon content) of the state of soils along the studied microcatenas clearly attest to their differentiation in the lateral and vertical directions because of the development of thermokarst microtopography. This is also accompanied by the differentiation of the vegetation cover with its mesophytic character and higher density in the microlow. It is probable that the removal of soluble salts and sodium from this soil with its neutral reaction will favor the further accumulation of humus and deepening of the humus horizon. The postagrogenic transformation of the soil on the top of byllars proceeds much slower. However, in the case of the fast melting of ground ice under conditions of the absence of local drainage network, the transformation of the entire system into the dyuedya lake-the initial stage of the development of alas lakes-may be expected at the Churapcha site; such lakes and thermokarst badland already have appeared on the adjacent field at the Tabaga site (Figure 5B).

If we compare the climate-induced change of soils and cropland in Central Yakutia with those in other cold regions 
(Péwé, 1954; Poeplau et al., 2019; Stevenson et al., 2014; Archegova et al., 2004; Kaverin et al., 2019; Alekseev and Abakumov, 2018), we can see both similarities and differences. In Central Alaska, the similar change-the occurrence of thermokarst mounds-took place (Péwé, 1954), but after decades of cultivation, the contrast in microtopography decreased and even disappeared. This may be related to the fact that Central Alaska is not the area of the widespread development of the Yedoma landscapes, and melting ice lenses do not create the same problem for agriculture as melting ice wedges. As well as in Central Yakutia, the permafrost table does not return to the previous depth after the abandoning of former cropland in the north of European Russia and West Siberia (Alekseev and Abakumov, 2018; Kaverin et al., 2019). However, the warming in other regions may not result in strong cryogenic deformation of abandoned croplands, most likely because of a lower ice content in the underlying permafrost. At the same time, such soil processes as acidification, paludification, podzolization, and peat accumulation, which are characteristic for soils of cold humid regions, are not much better for agriculture than the solonetz development in alkaline soils in the ultra-continental climate of Central Yakutia. Intense cryogenic fissuring and cryoturbation of topsoil horizons may gradually destroy the dense solonetzic/ plowpan horizon, and the soil will evolve into a typical Cambisol. However, in the case of the fast melting of ground ice under conditions of the absence of a local drainage network, the transformation of the entire system into the dyuedya lake-the initial stage of the development of alas lakes-may be expected.

\section{CONCLUSION}

Under the conditions of global climate change, the degradation of the Yedoma ice complex is observed on arable fields of Central Yakutia with the formation of initial forms of alas development-byllars, or residual thermokarst mounds surrounded by the hollows above the polygonal network of melting ice wedges, and in some places, dyuedya or young thermokarst lakes confined to the intersections of actively melting ice wedges. Thus, thermokarst processes on arable land lead to a considerable transformation of the surface topography and soil cover of the former arable fields.

The abandonment of croplands under the conditions of the recent continuous warming of the climate does not result in the restoration of the initial landscape but strengthens negative impacts on soils. As a result of thermokarst, the development of microtopography, and downward shift of the permafrost table, the morphology of soils is reconstructed with a change in their classification position. The Cryosols are transformed into Solonetzes and eroded Cambisols, and the large spatial contrast in soil properties, such as $\mathrm{pH}$, bulk density, and organic carbon content, appears in the soil profiles.
Upon subsidence of the soils of slopes and microlows, their middle- and lower-profile horizons become compacted, whereas the lowermost horizons above permafrost are loosened because of the collapse of the underlying sediment above the melting ice wedges. The soils of slopes and microlows also display considerable changes in the distribution of $\mathrm{pH}$ in their profiles. The soil cover becomes more heterogeneous, and such contrasts in the soil properties at small distances are very negative for the use of these soils for crop growing.

The global warming in the studied region with very cold climate resulted in the total degradation of the cropland because of the development of byllar microtopography and melting of buried ice wedges. Those specialists anticipating better conditions for agriculture in cold areas because of climate warming could learn from this experience for more accurate predictions. However, in other cold regions beyond the areas with the Yedoma ice complex deposits, the situation may be more optimistic.

\section{DATA AVAILABILITY STATEMENT}

The original contributions presented in the study are included in the article/supplementary material, further inquiries can be directed to the corresponding author.

\section{AUTHOR CONTRIBUTIONS}

Conceptualization, RD; field and laboratory data acquisition, NF and $\mathrm{AD}$; data analysis and interpretation, all authors; writing-original draft preparation, $\mathrm{RD}$ and $\mathrm{AD}$; writing-review and editing, DK and SG; visualization, NF and $\mathrm{AD}$; project administration, $\mathrm{RD}$. All authors have read and agreed to the published version of the manuscript.

\section{FUNDING}

This study was supported by the Russian Foundation for Basic Research (project no. 19-29-05151) (data collection, conceptual generalization, and text writing). It was also performed within the framework of the Russian governmental assignment of the Institute of Geography no. 0148-2019-0006 (WRB classification and data arrangement according to international standards).

\section{ACKNOWLEDGMENTS}

We are grateful to all our colleagues for their help in completing this study, especially to Peter Schad for his help in determining the classification position of soils in the WRB system. 


\section{REFERENCES}

Alekseev, I., and Abakumov, E. (2018). Permafrost-affected Former Agricultural Soils of the Salekhard City (Central Part of Yamal Region). Czech Polar Rep. 8 (1), 119-131. doi:10.5817/cpr2018-1-9

Archegova, I., Kotelina, N., and Mazhitova, G. (2004). “Agricultural Use of Tundra Soils in the Vorkuta Area, Northeast European Russia," in Cryosols. PermafrostAffected Soils. Editor J. M. Kimble (Berlin Heidelberg: Springer-Verlag), 661-676. doi:10.1007/978-3-662-06429-0_34

Beck, H. E., Zimmermann, N. E., McVicar, T. R., Vergopolan, N., Berg, A., and Wood, E. F. (2018). Present and Future Köppen-Geiger Climate Classification Maps at 1-km Resolution. Sci. Data 5, 180214. doi:10.1038/sdata.2018.214

Boike, J., Grau, T., Heim, B., Günther, F., Langer, M., Muster, S., et al. (2016). Satellite-Derived Changes in the Permafrost Landscape of Central Yakutia, 2000-2011: Wetting, Drying, and Fires. Glob. Planet. Change 139, 116-127. doi:10.1016/j.gloplacha.2016.01.001

Brown, J., Ferrians, O. J., Jr., Heginbottom, J. A., and Melnikov, E. S. (1997). Circum-Arctic Map of Permafrost and Ground Ice Conditions. Washington, DC: USGS in Cooperation with the Circum-Pacific Council for Energy and Mineral Resources, Circum-Pacific Map Series CP-45. scale 1:10,000,000.

Crampton, L. (2019). Alaska's Agriculture Boom Is Driven by a Local-First Spirit. Available online: https://www.politico.com/story/2019/04/30/alaskasagriculture-boom-is-driven-by-a-local-first-spirit-1381727.

Desyatkin, R., Fedorov, A., Desyatkin, A., and Konstantinov, P. (2015). Air Temperature Changes and Their Impact on Permafrost Ecosystems in Eastern Siberia. Therm. Sci. 19 (Suppl. 2), 351-360. S351-S360. doi:10.2298/ TSCI150320102D

Desyatkin, R. V. (2018). Climate Change and Dynamics of Permafrost Ecosystems of the Center of the Continental Cryolithozone of the Northern Hemisphere. Her. Russ. Acad. Sci. 88 (6), 494-501. doi:10.1134/S1019331618060072

Desyatkin, R. V., and Desyatkin, A. R. (2019). The Effect of Increasing Active Layer Depth on Changes in the Water Budget in the Cryolithozone. Eurasian Soil Sci. 52 (11), 1447-1455. doi:10.1134/S1064229319110036

Desyatkin, R. V. (2004). "Ecological Problems of the Use of Alas Land in Agriculture," in Measures on Implementation of the State Program on the Socio-Economic Development of Rural Areas up to 2006 (Moscow: Timiryazev Agric. Acad.), 40-52. [in Russian].

Desyatkin, R. V., Goryachkin, S. V., Konyushkov, D. E., Krasilnikov, P. V., Lebedeva, M. P., Bronnikova, M. A., et al. (2017). Cryosols in Perspective: A View from the Permafrost Heartland. Guidebook-Monograph for Field Excursions of the VII International Conference on Cryopedology. MoscowYakutsk: Inst. Geogr. RAS.

Desyatkin, R. V., Goryachkin, S. V., Konyushkov, D. E., Krasilnikov, P. V., Lebedeva, M. P., Bronnikova, M. A., et al. (2013). Diversity of Soils of Cold Ultra-Continental Climate. Guidebook-Monograph for the "Mammoth" UltraContinental WRB Field Workshop. Sakha-Yakutia, August 17-23, 2013 Moscow-Yakutsk: Inst. Geogr. RAS. Available online: https://www3.ls.tum. de/fileadmin/w00bds/boku/downloads/wrb/Guide_Sakha_final.pdf.

Desyatkin, R. V. (1991). Soil Formation in Alases. Soviet Soil Sci. 23 (4), 9-19.

Desyatkin, R. V. (2008). Soil Formation in Thermokarst Depressions-Alases of the Cryolithozone. Novosibirsk: Nauka. [in Russian].

Desyatkin, R. V. (1993). Syngenetic Soil Salinization During Alas Development. Eurasian Soil Sci. 25 (4), 38-46.

Elovskaya, L. G., and Konorovskii, A. K. (1978). Regionalization and Reclamation of Permafrost-Affected Soils of Yakutia. Novosibirsk: Nauka, 175. [in Russian]

Elovskaya, L. G. (1964). Soils of Arable Farming Regions in Yakutia and the Ways to Improve Their Fertility. Yakutsk Knizhn. Izd. [in Russian].

Food and Agriculture Organization of the United Nations (2006). Guidelines for Soil Description. 4th ed. Rome: FAO.

Gavril'ev, P. P., Ugarov, I. S., and Efremov, P. V. (2005). Cryogenic Processes and Tolerance of the Ice Complex Deposits in Central Yakutia Towards Modern Climate Change and Surface Disturbance. Nauka i Obrazovanie 40 (4), 84-87.

Gavriliev, P. P. (2008). "Inter-alas Agricultural Landscapes and Active Layer Trends and Dynamics in Response to a Warming Climate in Central Yakutia," in Proceedings of the Ninth International Conference on Permafrost. Editors D. L. Kane and K. M. Hinkel (Fairbanks: Univ. of Alaska, Institute of Northern Engineering), 499-505.
Gavriliev, P. P., Ugarov, I. S., and Efremov, P. V. (2001). Permafrost-Ecological Characteristics of Taiga Agrolandscapes, Central Yakutia. Izd. Inst. Merzlotoved. Zemli Sib Yakutsk: Izd. Inst. Merszlotoved. Zemli Sib. Otd. Ross. Akad. Nauk. [in Russian].

Grigor'ev, M. N., Skachkov, Yu. B., Fedorov, A. N., Desyatkin, R. V., and Maksimov, T. Kh. (2010). A Review of Modern Climate and Environmental Changes in the Sakha (Yakutia) Republic. Yakutsk: Izd. Inst. Merzlotoved. Zemli Sib. Otd. Ross. Akad. Nauk. [in Russian].

Iijima, Y., Fedorov, A. N., Park, H., Suzuki, K., Yabuki, H., Maximov, T. C., et al. (2010). Abrupt Increases in Soil Temperatures Following Increased Precipitation in a Permafrost Region, Central Lena River Basin, Russia. Permafrost Periglac. Process. 21, 30-41. doi:10.1002/ppp.662

Intergovernmental Panel on Climate Change (2014). Climate Change 2014: Synthesis Report. Contribution of Working Groups I, II and III to the Fifth Assessment Report of the Intergovernmental Panel on Climate Change. Editors Core Writing Team R. K. Pachauri and L. A. Meyer (Geneva, Switzerland: IPCC).

IUSS Working Group WRB (2015). World Reference Base for Soil Resources 2014, update 2015. International Soil Classification System for Naming Soils and Creating Legends for Soil Maps. World Soil Resources Reports No. 106 (Rome: FAO).

Iwahana, G., Machimura, T., Kobayashi, Y., Fedorov, A. N., Konstantinov, P. Y., and Fukuda, M. (2005). Influence of Forest Clear-Cutting on the Thermal and Hydrological Regime of the Active Layer Near Yakutsk, Eastern Siberia. J. Geophys. Res. 110, G02004. doi:10.1029/2005jg000039

Jones, A., Stolbovoy, V., Tarnocai, C., Broll, G., Spaargaren, O., and Montanarella, L. (2009). Soil Atlas of the Northern Circumpolar Region (Luxembourg: Office for Official Publications of the European Communities).

Jorgenson, M. T. (2013). "Thermokarst Terrains," in Treatise on Geomorphology. Glacial and Periglacial Geomorphology. Editors J. F. Shroder, R. Giardino, and J. Harbor (USA, San Diego: Academic Press), Vol. 8, 313-324. doi:10.1016/ b978-0-12-374739-6.00215-3

Jorgenson, M. T., Kanevskiy, M., Shur, Y., Moskalenko, N., Brown, D. R. N., Wickland, K., et al. (2015). Role of Ground Ice Dynamics and Ecological Feedbacks in Recent Ice Wedge Degradation and Stabilization. J. Geophys. Res. Earth Surf. 120 (11), 2280-2297. doi:10.1002/2015JF003602

Kaverin, D. A., Pastukhov, A. V., and Panjukov, A. N. (2019). Soil Temperature Regime in Postagrogenic Ecosystems Under the Expansion of Self-Restoring Succession of Tundra Vegetation (European Northeast of Russia). Earth's Cryosphere XXIII (5), 50-56. doi:10.21782/EC2541-9994-2019-5(505610.21782/kz1560-7496-2019-5(58-66)

Krasyuk, A. A., and Ognev, G. N. (1927). "Soils of the Lena-Amga Interfluve (Yakutsk Okrug)," in Materials of the Commission on the Study of Yakutian Autonomous Soviet Socialist Republic. Moscow: Izd. Akad. Nauk SSSR. [in Russian]

Lader, R., Walsh, J. E., Bhatt, U. S., and Bieniek, P. A. (2019). Agro-climate Projections for a Warming Alaska. Earth Interactions 22, 1-24.

Lyuri, D. I., and Goryachkin, S. V. (2008). "Global Land Use Change and its Specificity in Permafrost-Affected Regions: Consequences for Cryosols," in Ninth International Conference on Permafrost. Institute of Northern Engineering. Editors D. L. Kane and K. M. Hinkel (Fairbanks: University of Alaska Fairbanks), 1093-1097.

Neustroev, M. P., Ivanov, R. V., and Abramov, A. F. (2017). The Agricultural System in the Republic of Sakha (Yakutia) for the Period 2016-2020: Methodological Manuals. Yakutsk: YANIISH. [in Russian].

Olson, D. M., Dinerstein, E., Wikramanayake, E. D., Burgess, N. D., Powell, G. V. N., Underwood, E. C., et al. (2001). Terrestrial Ecoregions of the World: a New Map of Life on Earth. BioScience 51, 933-938. doi:10.1641/0006-3568(2001)051 [0933:teotwa]2.0.co;2

Péwé, T. L. (1954). Effect of Permafrost on Cultivated Fields, Fairbanks Area, Alaska. U.S. Geol. Surv. Bull. 989-F, 315-351. doi:10.3133/b989f

Poeplau, C., Schroeder, J., Gregorich, E., and Kurganova, I. (2019). Farmers' Perspective on Agriculture and Environmental Change in the Circumpolar North of Europe and America. Land 8, 190. doi:10.3390/land8120190

Rosenzweig, C., and Parry, M. L. (1994). Potential Impact of Climate Change on World Food Supply. Nature 367, 133-138. doi:10.1038/367133a0

Safronov, F. G. (1961). Russian Peasants in Yakutia in the 17th-Beginning of the 20th Centuries AD. Yakutsk: Izd. Sib. Otd. Akad. Nauk SSSR. [in Russian]. 
Schuur, E. A. G., and Mack, M. C. (2018). Ecological Response to Permafrost Thaw and Consequences for Local and Global Ecosystem Services. Annu. Rev. Ecol. Evol. Syst. 49, 279-301. doi:10.1146/annurev-ecolsys-121415032349

Shein, E. V. (2009). The Particle-Size Distribution in Soils: Problems of the Methods of Study, Interpretation of the Results, and Classification. Eurasian Soil Sci. 42 (3), 286-293. doi:10.1134/s1064229309030053

Shur, Y. L., and Jorgenson, M. T. (2007). Patterns of Permafrost Formation and Degradation in Relation to Climate and Ecosystems. Permafrost Periglac. Process. 18, 7-19. doi:10.1002/ppp.582

Skachkov, Yu. B. (2000). "Modern Climate Changes in Central Yakutia," in Climate and Permafrost: Integrated Studies in Yakutia (Yakutsk: Izd. Inst. Merzlotoved. Zemli Sib. Otd. Ross. Akad. Nauk), 55-63. [in Russian].

Stevenson, K. T., Rader, H. B., Alessa, L., Kliskey, A. D., Pantoja, A., Clark, M., et al. (2014). Sustainable Agriculture for Alaska and the Circumpolar North: Part II. Environmental, Geophysical, Biological and Socioeconomic Challenges. Arctic 67, 296-319. doi:10.14430/arctic4408

Timofeev, P. A., Isaev, A. P., and Shcherbakov, I. P. (1994). Forests of the Middle Taiga Subzone of Yakutia. Yakutsk: Izd. Yakutsk. Nauchn. Tsentra Sib. Otd. Ross. Akad. Nauk. [in Russian].

Tomirdiaro, S. V. (1978). Natural Processes and Development of the Territory in the Permafrost Zone. Moscow: Nedra. [in Russian].

van Reeuwijk, L. P. (2002). Procedures for Soil Analyses. Sixth edition. Wageningen: Int. Soil Ref. Inform. Centre.

Veremeeva, A., Nitze, I., Günther, F., Grosse, G., and Rivkina, E. (2021). Geomorphological and Climatic Drivers of Thermokarst Lake Area Increase
Trend (1999-2018) in the Kolyma Lowland Yedoma Region, North-Eastern Siberia. Remote Sensing 13, 178. doi:10.3390/rs13020178

Yoshikawa, K., Bolton, W. R., Romanovsky, V. E., Fukuda, M., and Hinzman, L. D. (2002). Impacts of Wildfire on the Permafrost in the Boreal Forests of Interior Alaska. J. Geophys. Res. 108, 8148. doi:10.1029/2001JD000438

Zol'nikov, V. G. (1954). "Soils of the Eastern Part of Central Yakutia and Their Use," in Materials on the Environmental Conditions and Agriculture in Central Yakutia (Moscow: Izd. Akad. Nauk SSSR), 1, 35-221. [in Russian].

Conflict of Interest: The authors declare that the research was conducted in the absence of any commercial or financial relationships that could be construed as a potential conflict of interest.

Publisher's Note: All claims expressed in this article are solely those of the authors and do not necessarily represent those of their affiliated organizations, or those of the publisher, the editors, and the reviewers. Any product that may be evaluated in this article, or claim that may be made by its manufacturer, is not guaranteed or endorsed by the publisher.

Copyright (c) 2021 Desyatkin, Filippov, Desyatkin, Konyushkov and Goryachkin. This is an open-access article distributed under the terms of the Creative Commons Attribution License (CC BY). The use, distribution or reproduction in other forums is permitted, provided the original author(s) and the copyright owner(s) are credited and that the original publication in this journal is cited, in accordance with accepted academic practice. No use, distribution or reproduction is permitted which does not comply with these terms. 